N. Anfimov, I. Chirikov-Zorin ${ }^{1}$, A. Dovlatov,

O. Gavrishchuk, A. Guskov, N. Khovanskiy, Z. Krumshtein, R. Leitner, G. Meshcheryakov, A. Nagaytsev, A. Olchevski, T. Rezinko, A. Sadovskiy, Z. Sadygov, I. Savin, V. Tchalyshev, I. Tyapkin, G. Yarygin, F. Zerrouk ${ }^{2}$

\title{
BEAM TEST OF «SHASHLYK» EM CALORIMETER PROTOTYPES READOUT BY NOVEL MAPD WITH SUPERHIGH LINEARITY
}

Presented at the 11th Pisa Meeting on Advanced Detectors «Frontier Detectors for Frontier Physics», May 24-30, 2009, La Biodola, Isola d'Elba, Italy

\footnotetext{
${ }^{1}$ E-mail: chirikov@nusun.jinr.ru;

${ }^{2}$ Zecotek Photonics Inc., Singapore
} 
Анфимов Н. и др.

Исследование на пучке ускорителя прототипов ЭМ-калориметров

«Шашлык» со съемом информации новыми MAPD

со сверхвысокой линейностью

Основные свойства двух разных модулей ЭМ-калориметров «Шашлык» со съемом информации новыми микропиксельными лавинными фотодиодами (MAPD) с очень высокой плотностью пикселей исследованы на тестовом пучке T9 CERN PS. В наших тестах использовались MAPD-3A с плотностью пикселей $1,5 \cdot 10^{4}$ мм $^{-2}$ и площадью $3 \times 3$ мм, изготовленные компанией «Zecotek» (Сингапур).

Работа выполнена в Лаборатории ядерных проблем им. В.П. Джелепова ОИЯИ.

Препринт Объединенного института ядерных исследований. Дубна, 2009

Anfimov N. et al.

E13-2009-87

Beam Test of «Shashlyk» EM Calorimeter Prototypes Readout

by Novel MAPD with Superhigh Linearity

The main properties of two different «Shashlyk» EM calorimeter modules readout by novel micropixel avalanche photodiodes (MAPD) with microwell structure and very high density of pixels were studied at the T9 CERN PS test-beam facility. The MAPD-3A with density of pixels $1.5 \cdot 10^{4} \mathrm{~mm}^{-2}$ and area $3 \times 3 \mathrm{~mm}$ manufactured by Zecotek company (Singapore) were used in our test.

The investigation has been performed at the Dzhelepov Laboratory of Nuclear Problems, JINR. 
In scintillator calorimeters the photomultipliers (PMT) are used as photodetectors. Relatively large size PMT does not permit one to make calorimeters with the high granularity and, more substantially they do not allow operation in the strong magnetic fields, which are often present in the experiment. The application of photodiodes for light detection, at least partially, avoids the above disadvantages. In this paper first beam test results of two different «Shashlyk» EM calorimeter prototype modules readout by novel micropixel avalanche photodiodes (MAPD) with superhigh linearity are presented.

The «Shashlyk» EM calorimeter consists of stack of alternative layers of lead and plastic scintillator readout by means of WLS fibers passing through holes in the scintillator and lead.

The first, ECAL0, module is constructed from the alternating layers of $2 \mathrm{~mm}$ thick lead and $4 \mathrm{~mm}$ thick scintillator plates with dimensions $12.1 \times 12.1 \mathrm{~cm}^{3}$. They are readout by means of 64 WLS fibers [1] grouped in four bundles with 16 fibers per bundle. The module consists of 66 lead/scintillator pairs, which corresponds to a total length of $42 \mathrm{~cm}$ or 25 radiation lengths.

The second, NICA, module is constructed from the alternating layers of $0.275 \mathrm{~mm}$ thick lead and $1.5 \mathrm{~mm}$ thick scintillator plates with dimensions $11 \times$ $11 \mathrm{~cm}^{3}$, which are readout by means of 144 WLS fibers [2] and grouped in 9 bundles with 16 fibers per bundle. The module composes of 300 lead/scintillator pairs, which corresponds to a total length of $55.5 \mathrm{~cm}$, or 15.9 radiation lengths.

At the end of modules the fiber bundles are glued to the cone light guide, with the other side diameter matching the MAPD sensitive area.

For comparison the calorimeter cells (bundles) were first readout by PMT EMI 9814B and then by novel MAPD-3A with microwell structure and very high density of pixels [3]. This device has a common $p-n$ junction on the $n$-type silicon substrate and a clear sensitive surface as a standard APD. Here both, the matrix of avalanche regions and the individual passive quenching elements, are placed inside of the silicon substrate [4]. The independent avalanche regions (vertical channels) with individual microwells for charge trapping/collection are created at a depth of about 3-5 $\mu \mathrm{m}$ using a special distribution of the inner electric field. Charge collection in individual microwells provides the local self-quenching of avalanche processes in the MAPD.

The MAPD-3A with gain $2 \cdot 10^{4}$, photon detection efficiency $(\mathrm{PDE}) \simeq 10 \%$ in the green region and density of pixels $1.5 \cdot 10^{4} \mathrm{~mm}^{-2}$ and area $3 \times 3 \mathrm{~mm}$ manufactured by Zecotek company (Singapore) [5], were used. 
In the test the MAPD of one module were fixed on the copper plate placed in thermoisolated cooling unit. During the tests the temperature was kept at $15^{\circ} \mathrm{C}$ by Peltier element. The signals from MAPD were amplified by amplifiers with a gain of about 14 and measured by QDC V792 (CAEN).

The main properties of calorimeter modules were studied at the T9 CERN PS test-beam facility with intensity of about $5 \cdot 10^{4}$ particles per second. The comparative results of studies are presented in Fig. 1 and Fig. 2. One can see, that the good linearity and energy resolution comparable with PMT was obtained for MAPD readout in the whole energy range for both calorimeter prototypes.

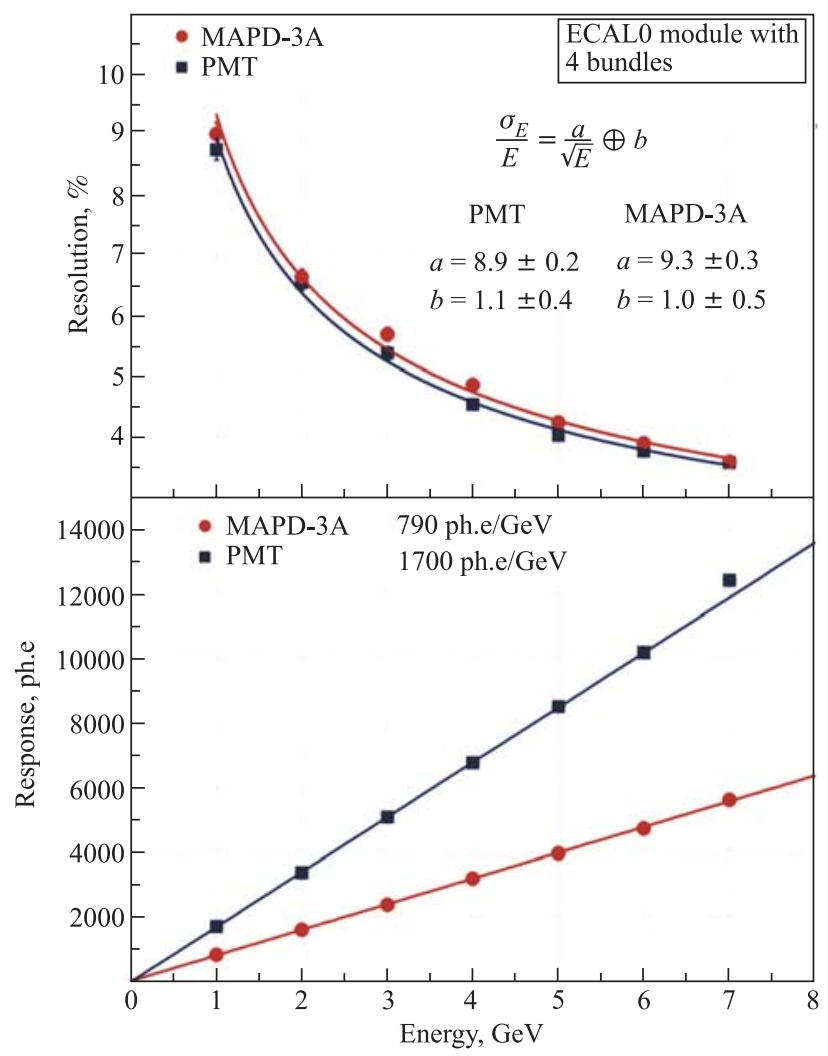

Fig. 1. Responses and energy resolutions ECAL0 module readout by PMT EMI 9814B and MAPD-3A at $T=15{ }^{\circ} \mathrm{C}$ versus electron beam energy 
In the future we plan to continue the tests of calorimeter modules readout also by new generation MAPD-3N. The comparison of typical LED spectra of MAPD-3A and new generation MAPD-3N for low-intensity light pulses with the same number of photoelectrons are shown in Fig. 3.

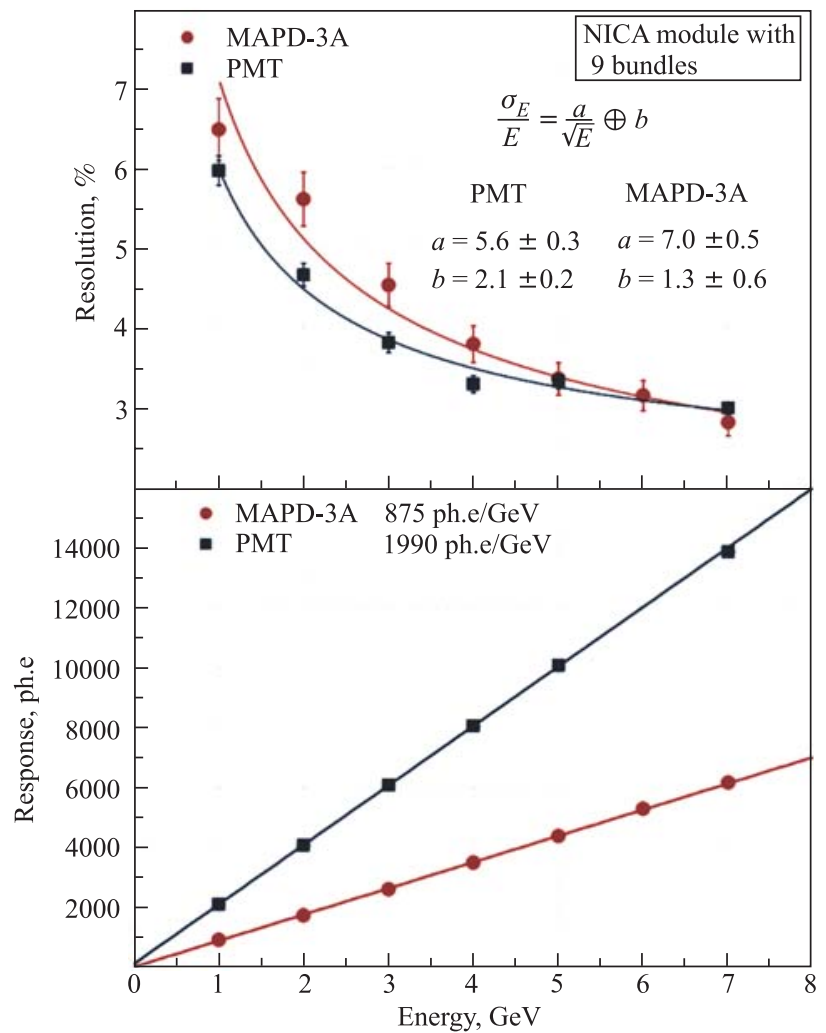

Fig. 2. Responses and energy resolutions NICA module readout by PMT EMI 9814B and MAPD-3A at $T=15{ }^{\circ} \mathrm{C}$ versus electron beam energy

The MAPD-3N pixel gain, average number of fired pixels for one detected photon due to optical cross-talk [6] and PDE for different light wavelengths depending on bias voltage are show in Fig. 4. The MAPD properties were studied by means of a fast LED using low-intensity light flashes [7]. The PDE was 


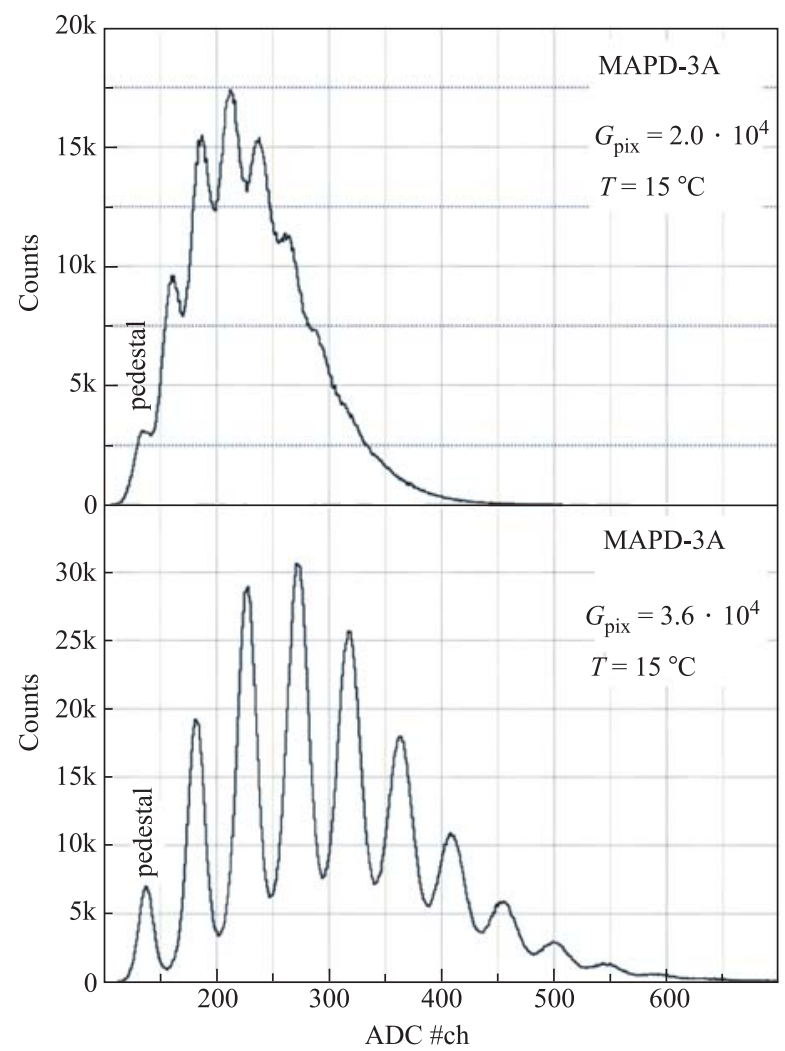

Fig. 3. Typical LED spectra of MAPD-3A and MAPD-3N for low-intensity light pulses with number of 3.5 ph.e at $T=15{ }^{\circ} \mathrm{C}$

estimated relative to the standard spectral response of Hamamatsu photosensor H6780-04.

The $\gamma$ spectra of ${ }^{137} \mathrm{Cs}$ on Lutetium Fine Silicate (LFS) scintillation crystal [5] are shown in Fig. 5 for direct comparison of characteristics of PMT and MAPD$3 \mathrm{~N}$. One can see that the energy resolution obtained with MAPD-3N is comparable with PMT EMI 9814B.

First beam test of «Shashlyk» EM calorimeter prototypes readout by PMT and novel MAPD-3A were performed. The results obtained for PMT and MAPD$3 \mathrm{~A}$ with very high density of pixels are very comparable, therefore, novel MAPD can used for «Shashlyk» EM calorimeters readout instead of PMT. 


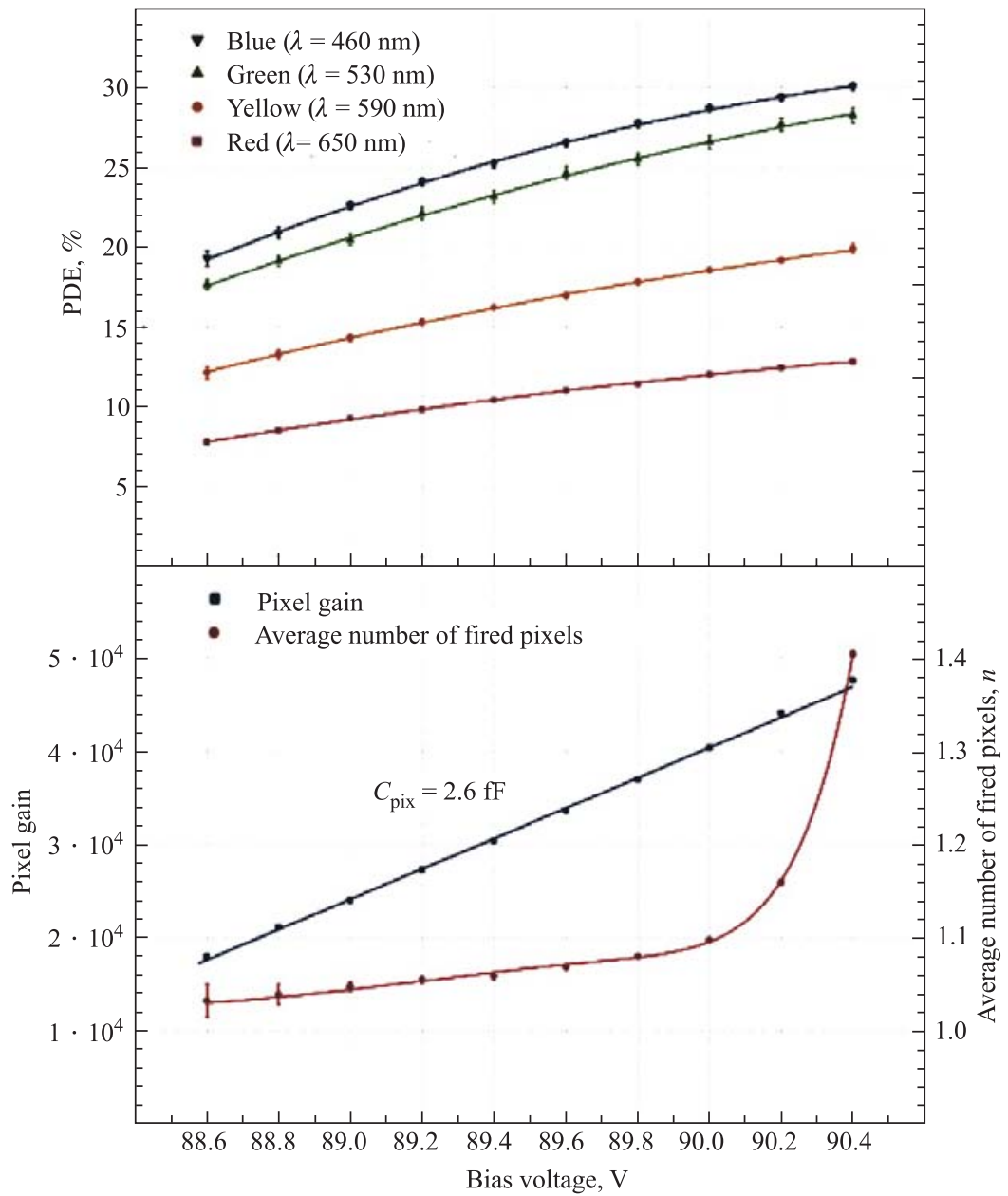

Fig. 4. Pixel gain, PDE and average number of fired pixels versus bias voltage for MAPD-3N at $T=15{ }^{\circ} \mathrm{C}$ 


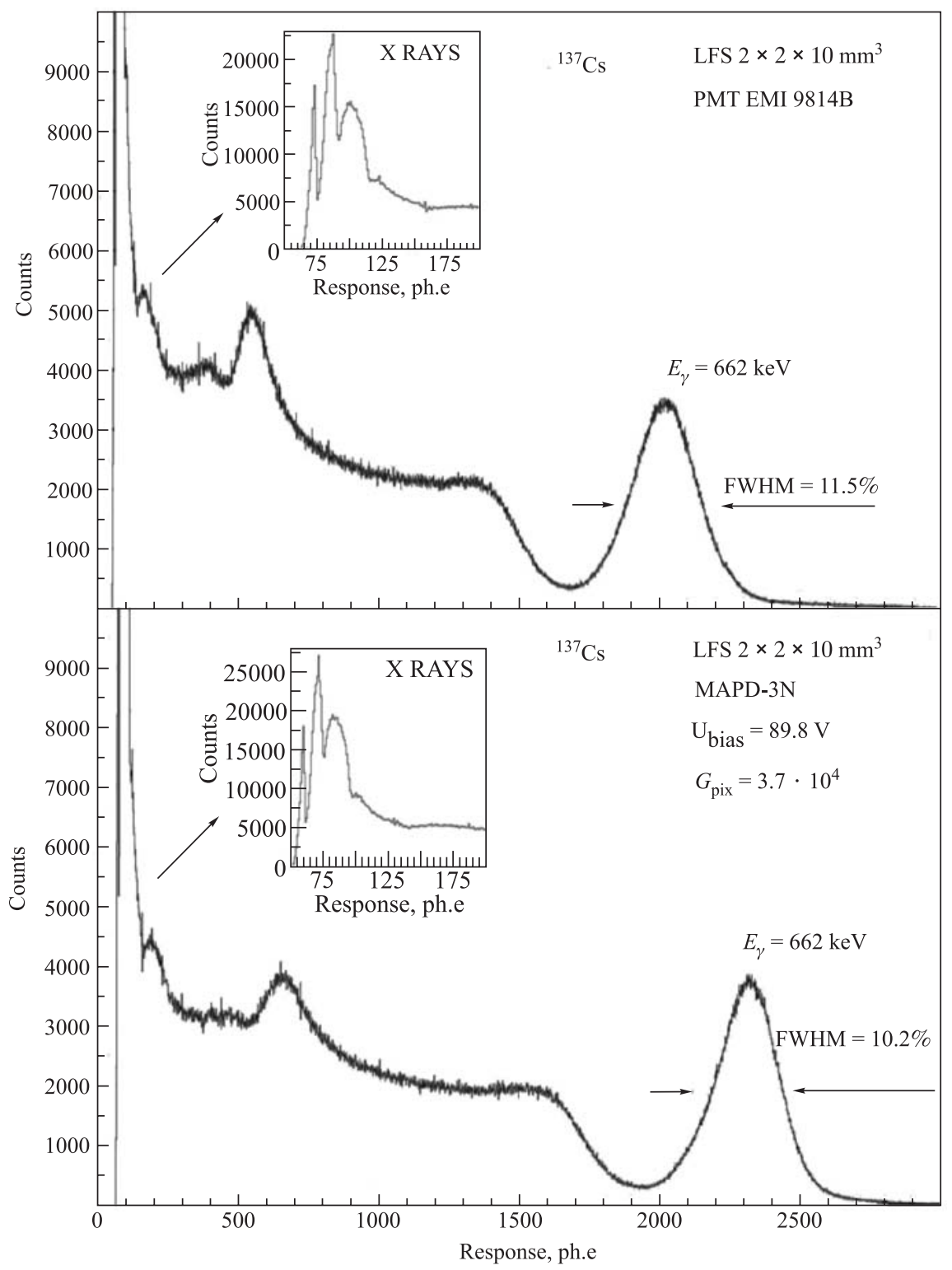

Fig. 5. Amplitude spectra obtained with PMT EMI 9814B and MAPD-3N at detection ${ }^{137} \mathrm{Cs} \gamma$ quanta with a LFS scintillation crystal of size $2 \times 2 \times 10 \mathrm{~mm}^{3}$ at $T=15{ }^{\circ} \mathrm{C}$ 


\section{REFERENCES}

1. Arefev A. V. et al. // Instr. Exp.Tech. 2008. V.51. No. 4, P. 511.

2. Atoian G. S. et al. // Nucl. Instr. Meth. A. 2008. V.584. P. 291.

3. Sadygov Z. et al. // Nucl. Instr. Meth. A. 2006. V. 567. P. 70.

4. Sadygov Z. Ya. Russian Patent Application \#2005108324 of 24.03.2005.

5. http://www.zecotek.com/

6. Renker D. // Nucl. Instr. Meth. A. 2006. V.567. P. 48.

7. Chirikov-Zorin I. et al. // Nucl. Instr. Meth. A. 2001. V.456. P. 310.

Received on June 8, 2009. 


\section{Корректор T. Е. Попеко}

Подписано в печать 4.08.2009.

Формат $60 \times 90 / 16$. Бумага офсетная. Печать офсетная.

Усл. печ. л. 0,68. Уч.-изд. л. 0,94. Тираж 325 экз. Заказ № 56676.

Издательский отдел Объединенного института ядерных исследований 141980, г. Дубна, Московская обл., ул. Жолио-Кюри, 6.

E-mail: publish@jinr.ru www.jinr.ru/publish/ 